九州大学学術情報リポジトリ

Kyushu University Institutional Repository

\title{
Innovative Biotechnological Applications of Galdieria Sulphuraria-Red Microalgae (GS-RMA) in Water Treatment Systems
}

Maamoun, Ibrahim

Department of Earth System Science and Technology, Interdisciplinary Graduate School of Engineering Sciences, Kyushu University

Bensaida, Khaoula

Department of Earth System Science and Technology, Interdisciplinary Graduate School of Engineering Sciences, Kyushu University

Eljamal, Ramadhan

Department of Earth System Science and Technology, Interdisciplinary Graduate School of Engineering Sciences, Kyushu University

Falyouna, Omar

Department of Earth System Science and Technology, Interdisciplinary Graduate School of Engineering Sciences, Kyushu University

他

https://doi.org/10.5109/4102483

出版情報: Proceedings of International Exchange and Innovation Conference on Engineering \& Sciences (IEICES). 6, pp. 163-170, 2020-10-22. Interdisciplinary Graduate School of Engineering Sciences, Kyushu University

バージョン：

権利関係 : 


\title{
Innovative Biotechnological Applications of Galdieria Sulphuraria-Red Microalgae (GS-RMA) in Water Treatment Systems
}

\author{
Ibrahim Maamoun, Khaoula Bensaida, Ramadan Eljamal, Omar Falyouna, Yuji Sugihara, Osama Eljamal ${ }^{1}$ \\ Department of Earth System Science and Technology, Interdisciplinary Graduate School of Engineering Sciences, \\ Kyushu University, Fukuoka, Japan \\ ${ }^{1}$ Corresponding author email: osama-eljamal@kyudai.jp
}

\begin{abstract}
In this study, mini review is introduced on the features of the red microalgae (RMA) and its biotechnological potential in different applications. Since it has unique extremophilic features, Galdieria Sulphuraria (GS) is considered to be a perfect microorganism candidate for various biotechnological applications in water treatment systems. Special interest has been oriented towards the applications of GS in water treatment systems, such as nutrients, biological oxygen demand (BOD) and heavy metals (HMs) removal from wastewater. Also, different future prospects have been suggested in terms of the new and innovative applications of GS in water treatment based on the gaps in the literature, including phycoremediation of HMs, bio-resin production, bio-substrate for nanoparticles, and pharmaceuticals removal from wastewater. Finally, the challenges and limitations of employing GS in biotechnological applications have been reviewed, which revealed that using GS has a great potential in largescale outdoor cultivation without becoming contaminated with other microorganisms.
\end{abstract}

Keywords: Red Microalgae (RMA); Galdieria Sulphuraria (GS); Water treatment systems; Biotechnological applications.

\section{INTRODUCTION}

The red microalga (RMA) is that kind of algae which belongs to the class Cyanidiophyceae. The formerly mentioned class represents a group of unicellular microorganisms which goes back to around 1.3 billion years old ancestral RMA [1,2]. This unicellular RMA has three main genera classifications, Cyanidioschyzon Merolae, Cyanidium Caldarium, and Galdieria Sulphuraria (GS). Cyanidioschyzon Merolae is well known for its size and shape characteristics as small (2 $\mu \mathrm{m})$ and club-shaped haploid genus (Fig. 1a) [3]. The other two genera are alike some extent in the morphological features. Hence, up to 1981, Cyanidium Caldaruim was considered as the synonym genus for Galdieria Sulphuraria (GS) [4,5].

All kinds of RMA have a great adaptability to the strong acidic ( $\mathrm{pH} 0.5-3.5)$ and high temperature $\left(38-56^{\circ} \mathrm{C}\right)$ conditions [6-8]. Such extremophilic features enables the RMA of growing in habitats where other microorganisms cannot tolerate. Therefore, RMA inhabits different geothermal environments, endolithic habitats around hot sulfur springs, boiling mud pools, and hot acidic waters [9]. Furthermore, RMA has an impressive metal tolerance which enables it to grow in a very toxic environments (rich with heavy metals) where other microorganisms are absent [10]. Recently, owing to the unique features of $G S$ in contrast with the other RMA genera, its potential in the biotechnological applications has been intensively studied. The unicellular cells of $G S$ have a spherical shape with thick walls (Fig. 1c). In addition to the previously mentioned acidophilic and thermophilic unique characteristics, $G S$ has the ability to exhibit special metabolism features through growing autotrophically, heterotrophically and mixotrophically $[11,12]$. Hence, the cells of $G S$ are considerable recognized, comparing with that of Cyanidium Caldaruim, owing to the heterophonic growth in the dark $[13,14]$. Moreover, the cell size of $G S$ is larger than the other RMA genera, which is preferable for storing vacuole and energy reserve products [15-18].
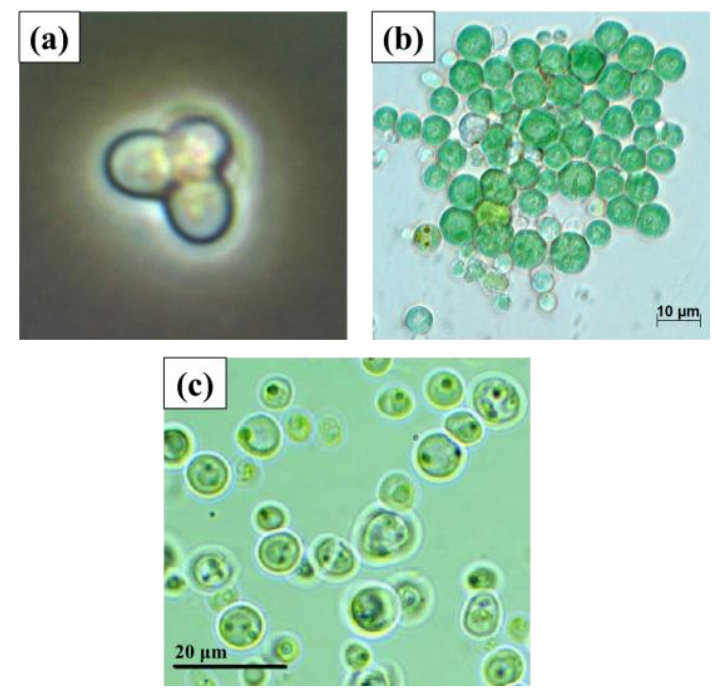

Fig. 1. Microscopic images showing the morphological characteristics of (a) Cyanidioschyzon Merolae, (b) Cyanidium Caldarium, and (c) Galdieria Sulphuraria $[5,19,20]$.

In this study, mini review is introduced on the unique features of the RMA and its biotechnological potential in different applications. Special interest has been oriented towards the applications of $G S$ in water treatment systems. Also, different future prospects have been suggested in terms of the new and innovative applications of $G S$ in water treatment based on the gaps in the literature. Finally, the challenges and limitations of employing $G S$ in biotechnological applications have been reviewed. 


\section{BIOTECHNOLOGICAL POTENTIAL $(G S)$}

The unique features of $G S$ give it a great potential in several biotechnological applications. Hence, in the following sections, different aspects of employing GS in various biotechnologies are reviewed.

\subsection{Biofuel Production}

There will be a serious rise in the global biofuel production by around 1.7 million barrels per day over the period between 2010 to 2040 [21]. Additionally, there is a rapid and continuous increase in the consumption of the fossil fuel all over the world within the last three decades. Hence, the need for a new and renewable energy sources has been emerged and the research on such aspect has dramatically increased. The biofuel production from microalgal biomass has attracted great attention recently as one of the possible solutions $[22,23]$. The microalgae biomass could be one of the most promising renewable resources for the regeneration of different types of biofuels, including bioethanol and biodiesel $[24,25]$. The rabid and sustainable growth of microalgae makes it a perfect biomass resource towards a viable biofuel production. The high content of carbohydrates in microalgae, which sometimes exceeds $50 \%$ of their dry weight, encouraged different researchers to conduct several studies on employing microalgal resources in bioethanol production $[23,25,26]$.

Apparently, there is a lack of knowledge concurring the use of RMA as a renewable biomass resource for biofuel production. Despite the several advantages of the biofuel production by microalgal biomass, such technology must overcome some issues when it comes to the real competition in the fuel market. One of the major obstacles is the possible contamination of the microalgae with other microorganisms during the largescale outdoor cultivation processes, which affects the quality and the quantity of the produced biofuel through the inhibition of the algal growth as well as the decrease in the quality of the high-value products. Several studies have been focused on investigating the optimal culture and cultivating conditions for the microalgae, in addition to examining the microalgal chemical composition change by the effect of nutrients (i.e., phosphate, nitrogen and sulfur) $[21,27,28]$. Such studies confirmed the cruciality of the cultivation conditions of microalgae for the biofuel production viability. In this regard, RMA such as $G S$ has great superiority to other microalgae in solving such cultivation problems. $G S$ has a promising potential in producing high-quality biofuel with large quantities without any worries regarding becoming contaminated with other microorganisms. Moreover, the high tolerance of $G S$ to the extreme conditions of $\mathrm{pH}$ and temperature provides an effective way to control the composition of the large-scale cultures.

\subsection{Nutritional Applications}

Microalgae has the ability to produce glycogen, which serves as a store of glucose, as energy and carbon reserves [29]. Glycogen has better characteristics than starch in nutritional applications owing to its solubility in cold water and the easy accessibility by enzymes. Unlike other microalgae, RMA can accumulate highly branched glycogen, such as Amylopectin, which is well-known to be used in different products including sports drinks and peritoneal dialysis solutions. GS-RMA could be a viable cheap source for glycogen production, as it can produce glycogen up to $50 \%$ of its dry cell weight $[30,31]$. Other autotrophic or heterotrophic microorganisms which act as a glycogen source and suffer from the growth limitations, exhibiting low glycogen production [32]. GS, as a mixotrophic cultures, can produce large amounts of glycogen 10 times greater than that of other autotrophic or heterotrophic cultures [33].

Microalgal biomass contains high content of protein which can be integrated in different food industries. However, there are different technological difficulties when it comes to introducing the microalgal-based ingredients into food industry [34]. The most concerning issue is the unattractive green-brownish color which is usually associated with the green microalgae. Moreover, green microalgae develop a fishy smell gradually during the long storing time which could be an obstacle because of the unpleasant feeling [35]. Furthermore, the bacterial contamination of the green microalgae could seriously deteriorate the commercial quality of the microalgal biomass. Hence, GS-RMA could easily overcome such drawbacks of the green microalgae. The biomass of $G S$ is colorless, normally not contaminated with other microorganisms, and shelf-life oxidation could be negligible. Nutritional applications of $G S$ were suggested because of the richness of its cell walls with protein (average of 29\%) and polysaccharides (average of 66\%) [35].

\subsection{Recovery of Rare Metals}

One of the important biotechnological applications of $G S$-RMA is the recovery or rare earth metals. The cell walls of $G S$ have the ability to bi-sorb the precious metals from the metal-containing wastewaters, even at very low concentrations [36]. GS could selectively recover several metals from water such as lanthanides, gold $(\mathrm{Au})$, palladium $(\mathrm{Pd})$, and copper $(\mathrm{Cu})$. Even at very low $\mathrm{pH}$ $(1.5-2.5), G S$ could effectively recover around $90 \%$ of low lanthanides concentration $(0.5 \mathrm{mg} / \mathrm{L})$ from aqueous solutions via cell fractionation without any genetic manipulation of treatment of the cells [36]. Furthermore, more than $90 \%$ of $\mathrm{Au}$ (III) and Pd (II) were recovered from aqua-regia-based metallic wastewater, within significantly low concentration conditions which limited the use of chemical or pyro-metallurgic recycling [37].

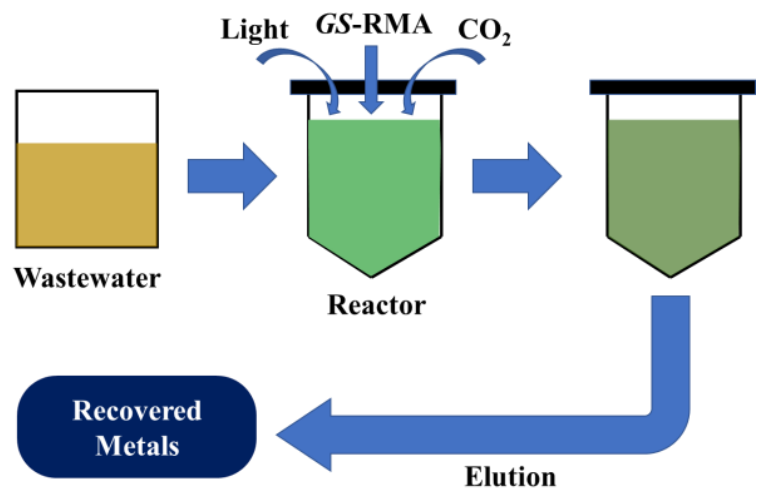

Fig. 2. Schematic of metal recovery system from wastewaters via employing $G S$-RMA.

Reviewing the literature revealed that different algae types (Spirulina platensis, Chlamydomonas reinhardtii, Chlorella sp., Chloroidium saccharophilum..., etc.) have been considered for metals bio-sorption from wastewaters and aqueous mediums such as $\mathrm{Cu}$ (II), 
Cr(III), Zn (II), Mg (II), Cd (II) [38]. However, only few reports have been reported on the use of $G S$ despite its several properties, which confirms the gap in the literature on this aspect. Hence, a simple and efficient system for the recovery of metals from wastewaters could be suggested for investigation (Fig. 2), in which it is expected that the entire process could be completed within only one hour.

\subsection{Biogas Production}

Employing the microalgae-based technologies in biogas production is one of the promising applications. Utilizing RMA as a biomass resource within the anaerobic digestion system could be very efficient in inducing the produced amount of biogas. The photosynthesis of RMA will be executed via the resulted $\mathrm{CO}_{2}$ from the methanogenesis stage in addition to the light energy. That will be cost-effective as there will be no need for external $\mathrm{CO}^{2}$ flow. Furthermore, the excess microalgal biomass in the system can be reutilized as substrate for the anaerobic digestion stage. Using GS-RMA in such system could be preferable cause of its auto-, hetero-, and mixotrophic ability, which could be also beneficial in terms of the required energy for the metabolism. Such combined system could be very promising within wastewater treatment plants (WWTPs) to achieve both wastewater treatment and biogas production.

\section{WATER TREATMENT APPLICATIONS}

Since it has unique extremophilic features, GS-RMA is considered to be unrivaled microorganism candidate for various biotechnological applications in water treatment systems. The possible applications of $G S$ in water treatment systems with respect to its characteristics can be summarized in Table 1.

Table 1. Possible water treatment applications of $G S$ considering its unique features.

\begin{tabular}{|c|c|c|}
\hline No. & Feature & Designated Application \\
\hline 1 & $\begin{array}{l}\text { Enormous metabolic } \\
\text { versatility in the } \\
\text { utilization of carbon } \\
\text { sources (including a } \\
\text { large range of sugars } \\
\text { and alcohols) for } \\
\text { heterotrophic } \\
\text { growth. }\end{array}$ & $\begin{array}{l}\text { Perfect choice for the } \\
\text { removal of nutrients } \\
\text { and dissolved organic } \\
\text { carbon from urban } \\
\text { wastewater (UWW). }\end{array}$ \\
\hline 2 & $\begin{array}{l}\text { Spherical shape with } \\
\text { thick-walled cells. }\end{array}$ & $\begin{array}{l}\text { Higher specific surface } \\
\text { area towards selective } \\
\text { metal precipitation and } \\
\text { for metal bio-sorption } \\
\text { from wastewater. }\end{array}$ \\
\hline 3 & $\begin{array}{l}\text { Remarkable } \\
\text { acidophilic ability. }\end{array}$ & $\begin{array}{l}\text { Biological Oxygen } \\
\text { Demand (BOD) and } \\
\text { nutrients (phosphorus, } \\
\text { nitrogen-forms) } \\
\text { removal from } \\
\text { municipal wastewater. }\end{array}$ \\
\hline 4 & $\begin{array}{l}\text { High resistance to } \\
\text { high metal } \\
\text { concentrations in } \\
\text { aqueous solutions } \\
\text { (even at low pH < } \\
2.5 \text { ). } \\
\end{array}$ & $\begin{array}{l}\text { Recovery of rare } \\
\text { metals from industrial } \\
\text { wastewater (even if } \\
\text { present at low } \\
\text { concentrations) or from } \\
\text { solid waste materials. }\end{array}$ \\
\hline
\end{tabular}

\subsection{Wastewater Treatment (WWT)-BOD \& Nutrients Removal}

Among the emerging wastewater treatment (WWT) technologies, algal-based systems hold promise as greener and sustainable alternatives to the current practice. Metabolic capabilities of algae enable them to grow in wastewaters, ingesting their organic- and nutrient-contents. In contrast to the current energyintensive technologies, algal processes can be driven by energy derived either from sunlight or from the wastewater itself [39]. Depending on their metabolic choice of sources of carbon and energy, algal systems are classified as photoautotrophic, heterotrophic or mixotrophic. Photoautotrophic and chemoheterotrophic systems have been adopted in many applications including WWT. However, applications of mixotrophic systems are currently limited even though they can be seen to be the most suitable ones for WWT from a metabolic perspective [40].

Mixotrophic cultures (such as $G S$ ) are versatile in that, they can obtain their carbon and energy needs either from organic or inorganic chemicals. Therefore, it can be considered as a combination of both photoautotrophic and chemoheterotrophic processes as shown in Fig. 3; each process can occur independent of the other resulting in accumulation/depletion of $\mathrm{CO}_{2}$ and $\mathrm{O}_{2}$.

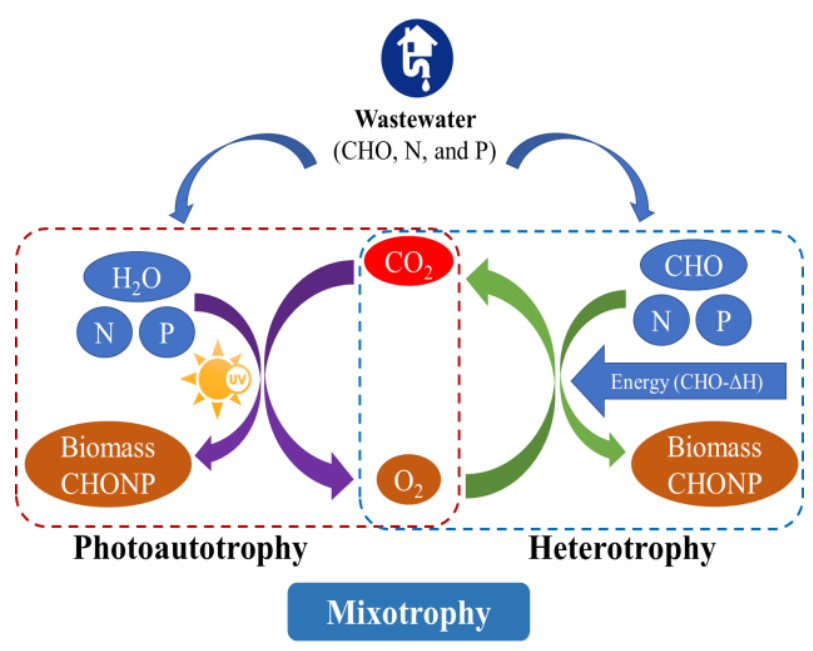

Fig. 3. Schematic of mixotrophic process for utilizing nutrient in wastewater and energy from light (in photoautotrophy) or from organics (in heterotrophy), modified from [41].

Typical wastewater treatment plants (WWTPs) equipped with secondary treatment processes are able to meet the discharge levels for organic carbon [quantified as Biochemical Oxygen Demand (BOD)], but fail to meet the discharge levels for phosphorus $(\mathrm{P})$ and Nitrogen $(\mathrm{N})$. To meet the discharge limits for both $\mathrm{P}$ and N, WWTPs are now required to add tertiary treatment systems to treat the secondary effluent. As such, $G S$ is a promising strain for single-step urban wastewater treatment instead of the current two-step practices of secondary treatment followed by tertiary treatment.

Current secondary treatment by activated sludge organisms converts nearly $50 \%$ of the dissolved organic carbon (DOC) in the wastewater to carbon dioxide $\left(\mathrm{CO}_{2}\right)$. An algal system can theoretically oxidize the DOC in wastewater to $\mathrm{CO}_{2}$ and recapture the metabolic $\mathrm{CO}_{2}$ via 
photosynthesis. Thus, algal wastewater treatment would produce significantly more energy-rich biomass than current methods. Technologies are currently available to generate fuels from algal biomass. Mixotrophically derived $\mathrm{CO}_{2}$ from respiration and $\mathrm{O}_{2}$ from photosynthesis would also significantly reduce the total metabolic gas supply requirements relative to current secondary and tertiary processes. Based on the above, it is hypothesized that mixotrophic wastewater treatment using $G S$ could be employed for energy-positive urban wastewater treatment.

In Table 2, the reported removal efficiencies in the literature of the applied $G S$-WWT systems towards BOD and nutrients removal. Peter Lammers research group in Arizona State University, USA, has been working intensively on investigating the application of $G S$ in WWT from nutrient and BOD $[41,42]$. In their previously reported study, discharge standards (of $30 \mathrm{mg} / \mathrm{L}$ BOD; $10 \mathrm{mg} / \mathrm{L} \mathrm{N}$; and $1 \mathrm{mg} / \mathrm{L} \mathrm{P}$ ) were achieved for all three pollutants in less than 3 days, in a fed-batch bioreactor within in a pilot-scale system [41]. Moreover, in another study, around $99 \%$ and $98 \%$ removal efficiencies were achieved for phosphate and ammoniacal-nitrogen, respectively, within one week [42]. Furthermore, on the field application scale, Lammers' group recorded remarkable removal efficiencies of the three pollutants using $G S$.

Table 2. BOD and nutrients removal using GS in WWT applications.

\begin{tabular}{|c|c|c|}
\hline Ref. & $\begin{array}{l}\text { System } \\
\text { conditions }\end{array}$ & $\begin{array}{l}\text { BOD \& nutrients removal } \\
\text { efficiencies }\end{array}$ \\
\hline [41] & $\begin{array}{l}\text { Pilot scale } \\
\text { system was } \\
\text { deployed at a } \\
\text { local wastewater } \\
\text { treatment plant } \\
\text { (700 L } \\
\text { bioreactor fed by } \\
\text { primary } \\
\text { effluent). }\end{array}$ & $\begin{array}{ll}- & \mathrm{PO}_{4} \text { (around } 77 \% \text { of } \\
\text { initial } 4.2 \mathrm{mg} / \mathrm{L}) . \\
\mathrm{NH}_{3}-\mathrm{N} \text { (around } 67 \% \\
\text { of initial } 23.4 \mathrm{mg} / \mathrm{L}) . \\
\text { - } \\
\text { Around } 64 \% \text { BOD } \\
\text { removal (of initial } \\
55.4 \mathrm{mg} / \mathrm{L} \text { ) after } 2 \\
\text { days. }\end{array}$ \\
\hline [42] & $\begin{array}{l}\text { Batch tests } \\
\text { considering } \\
\text { primary-settled } \\
\text { wastewater. }\end{array}$ & $\begin{array}{l}\mathrm{PO}_{4} \text { (around 99\% of } \\
\text { initial } 12 \mathrm{mg} / \mathrm{L}) \\
\mathrm{NH}_{3}-\mathrm{N}(\text { around } 98 \% \\
\text { of initial } 35 \mathrm{mg} / \mathrm{L})\end{array}$ \\
\hline [43] & $\begin{array}{l}\text { Batch tests } \\
\text { considering } \\
\text { synthesized } \\
\text { wastewater } \\
\text { simulating the } \\
\text { concentrations of } \\
\mathrm{N} \text { and } \mathrm{P} \text { in the } \\
\text { primary effluent. }\end{array}$ & $\begin{array}{l}\mathrm{PO}_{4} \text { (around } 95.5 \% \text { of } \\
\text { initial } 19 \mathrm{mg} / \mathrm{L} \text { ) after } \\
7 \text { days. } \\
\mathrm{NH}_{3}-\mathrm{N} \text { (around } 56 \% \\
\text { of initial } 35 \mathrm{mg} / \mathrm{L} \text { ) } \\
\text { after } 10 \text { days. }\end{array}$ \\
\hline [44] & $\begin{array}{l}\text { Field study } \\
\text { considering } \\
\text { primary-settled } \\
\text { wastewater. }\end{array}$ & $\begin{array}{l}\mathrm{PO}_{4} \text { (around } 71-95 \% \\
\text { of initial } 15 \mathrm{mg} / \mathrm{L} \text { ) } \\
\text { after } 2 \text { days. } \\
\mathrm{NH}_{3}-\mathrm{N} \text { (around } 63- \\
89 \% \text { of initial } 6 \\
\mathrm{mg} / \mathrm{L} \text { ) after } 5 \text { days. } \\
\text { Around } 46-72 \% \\
\text { BOD removal (of } \\
\text { initial } 32 \mathrm{mg} / \mathrm{L} \text { ) after } \\
6 \text { days. }\end{array}$ \\
\hline
\end{tabular}

The unique acidophilic and thermophilic abilities of GSRMA in addition to the high metal tolerance to metals, provides several unique mechanisms for heavy metals (HMs) removal. In Table 3, several reported studies have been included related to the removal of heavy metals (HMs) via the incubation of $G S$ in aqueous solutions rich with the designated metals to be removed.

Table 3. Metals removal from aqueous solutions using $G S$ incubation.

\begin{tabular}{|c|c|c|c|}
\hline Ref. & $\begin{array}{l}\text { System } \\
\text { conditions }\end{array}$ & Metal & Removal \\
\hline [36] & $\begin{array}{l}\text { Semi-anaerobic } \\
\text { heterotrophic } \\
\text { conditions } \\
\text { (overnight } \\
\text { incubation). }\end{array}$ & $\mathrm{Cu}$ (II). & $\begin{array}{l}\text { Copper } \\
\text { accumulation } \\
\text { before } \\
\text { recovery. }\end{array}$ \\
\hline [37] & $\begin{array}{l}\text { After } 30 \mathrm{~min} \\
\text { incubation in } \\
\text { wastewater. }\end{array}$ & $\begin{array}{l}\mathrm{Au}(\mathrm{III}) \\
\text { and } \mathrm{Pd} \\
\text { (II). }\end{array}$ & Over $90 \%$. \\
\hline [45] & $\begin{array}{l}90 \mathrm{~min} \\
\text { incubation in } \\
\text { aqueous medium } \\
\text { at } 24^{\circ} \mathrm{C} \text {. }\end{array}$ & $\begin{array}{l}\mathrm{Cu}(\mathrm{II}) \\
\text { and } \mathrm{Pb} \\
\text { (II). }\end{array}$ & $\begin{array}{l}\text { Selective } \\
\text { biosorption to } \\
\text { Copper only. }\end{array}$ \\
\hline
\end{tabular}

\section{PROPOSED APPLICATIONS}

After reviewing the up to date accomplishments as well as the gaps within the literature on the use of the RMA in water treatment applications, the following ideas are proposed:

\subsection{Phycoremediation for HMs}

There is a lack of knowledge on the use of $G S$ in HMs removal from water as most of the reported studies only focused on the nutrients and BOD removal. However, the unique features of $G S$ make it a perfect candidate for an efficient HMs removal by different possible mechanisms via several phycoremediation processes (Fig. 4).

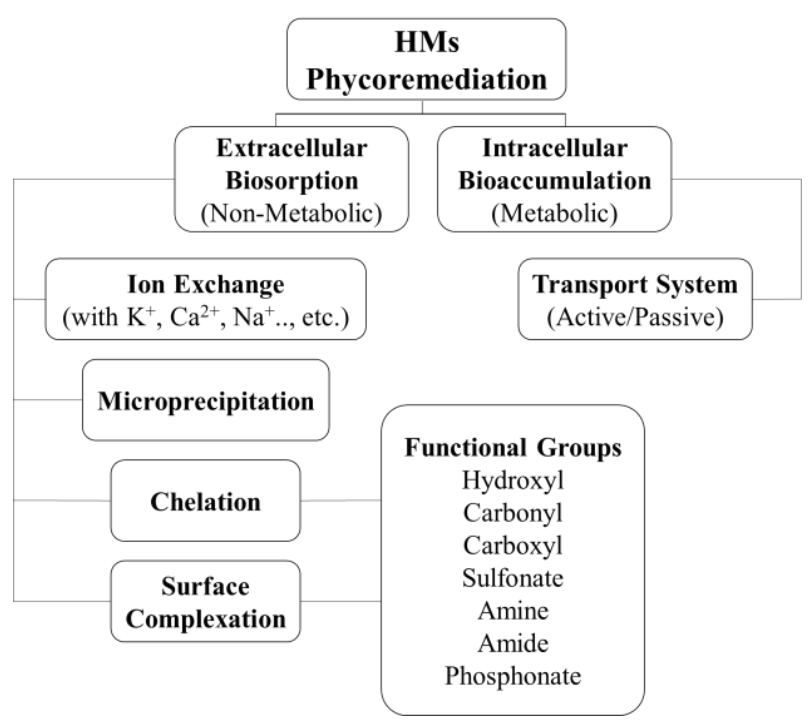

Fig. 4. Phycoremediation approaches for HMs removal by micro-algae, modified from [38].

\subsection{Pharmaceuticals Removal}

Environmental pollution due to the presence of pharmaceuticals in wastewater is one of the major threats to aquatic environment globally and it attracts great attention nowadays as one of the hot topics around the 
world. Huge amounts of pharmaceuticals enter the surface water bodies after the partial removal by the conventional WWTP [46-49]. Different studies have been focused on integrating different kinds of algae for this process [50]. However, there are almost no other studies concerned with integrating $G S$ in such applications. Therefore, investigating the removal of different pharmaceuticals (such as antibiotics and personal care products) by $G S$-based treatment system could be a promising technology and worth to be investigated

\subsection{Bio-resin Production}

Working on this aspect will represent a great novelty as it will be the first time to produce a bio-resin by immobilizing $G S$ on silica gel or proprietary polymer into adsorption columns for biotechnological cleanup of contaminated sites as well as the removal of HMs. Silica gel is an inorganic material which has several crucial features, such as the stability in acid conditions, no swelling, high mass selectivity, high porosity, and high specific surface area. Such properties make silica gel an ideal supporting material for environmental remediation applications. The main idea is modifying the silica gel surface via immobilizing the organic functional groups (i.e., carboxyl, hydroxyl, and carbonyl), which are derived from the $G S$-RMA. Such functional groups will enhance the ability of the composite for the bio-sorption of HMs as well as ion exchanging. Utilizing the bare microalgal powder could be ineffective to be used as column filling material because of its low density. Hence, immobilizing the $G S$ biomass on the supporting matrix of silica gel will increase the quality of the adsorbent to be used as column filling material for the continuous sorption process and to increase the chemical stability of the composite in general. The bond was proven previously in the literature by Fourier-transform infrared spectroscopy (FTIR) and scanning electron microscopyenergy dispersive spectrum (SEM-EDS) analyses. It was confirmed by the loss of the $\mathrm{Si}-\mathrm{O}$ stretching by the reduction in the silanol group $(\mathrm{Si}-\mathrm{OH})$ from the biomass condensation on the surface, in addition to the presence of $\mathrm{NH}$ and $\mathrm{CH}$ groups. Figure 5 shows the proposed production steps of the $G S /$ silica-gel bio-resin.

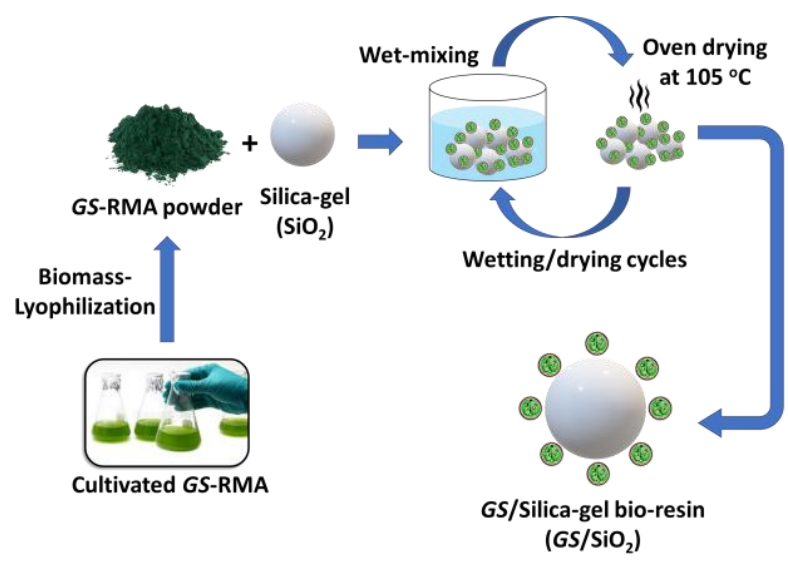

Fig. 5. Schematic of the production steps of Galdieria Sulphuraria/Silica-gel bio-resin $\left(G S / \mathrm{SiO}_{2}\right)$.

\subsection{Bio-substrate for Nanoparticles}

As one of the pioneering technologies in the world, nanotechnology still attracts great attention in the field of water treatment applications [51-56]. Nanoscale zero- valent iron $\left(\mathrm{Fe}^{0}\right)$ has great advantages in the removal of most of the soluble contaminants in aqueous solutions [57-59]. Combining the unique features of $\mathrm{Fe}^{0}$, such as the core shell structure and the high redox potential, with the special characteristics of $G S$-RMA could yield a novel composite with extraordinary remediation abilities [60-62]. Supporting the nanoparticles on the microalgal surface will provide various removal pathways for different contaminants via either the reactive surface of $\mathrm{Fe}^{0}$ or the organic functional groups of GS [63-67].

\section{CHALLENGES \& LIMITATIONS}

The main challenges for the application of microalgae in wastewater treatment are:

- The harvesting of the algae, due to the settling characteristics and operational conditions: can be overcome by the unconventional harvesting systems such as the paddlewheel system developed by Lammers' group [42].

- The control of biomass composition is complicated by the selection of the desired species: using $G S$ RMA has a great potential in largescale outdoor cultivation without becoming contaminated with other microorganisms, under both mixotrophic and heterotrophic conditions, owing to its tolerance with extreme $\mathrm{pH}$ and temperature conditions.

- The determination of an optimal ratio of algae and bacteria biomass: considering different operating conditions in the batch-scale before scaling up to the pilot level could be very beneficial in such aspect.

- The possible need for external $\mathrm{CO}_{2}$ present additional obstacles: such drawback will be overcome by the use of mixotrophic cultures such as GS-RMA which has the ability to accumulate $\mathrm{CO}_{2}$ within the system.

\section{REFERENCES}

[1] H.S. Yoon, J.D. Hackett, C. Ciniglia, G. Pinto, D. Bhattacharya, A molecular timeline for the origin of photosynthetic eukaryotes, Mol. Biol. Evol. 21 (2004) 809-818.

[2] H.S. Yoon, C. Ciniglia, M. Wu, J.M. Comeron, G. Pinto, A. Pollio, D. Bhattacharya, Establishment of endolithic populations of extremophilic Cyanidiales (Rhodophyta), BMC Evol. Biol. 6 (2006) 78.

[3] E. Yoshimura, S. Nagasaka, Y. Sato, K. Satake, S. Mori, Extraordinary high aluminium tolerance of the acidophilic thermophilic alga, Cyanidium caldarium, Soil Sci. Plant Nutr. 45 (1999) 721724.

[4] W. Gross, C. Schnarrenberger, Heterotrophic growth of two strains of the acido-thermophilic red alga Galdieria sulphuraria, Plant Cell Physiol. 36 (1995) 633-638.

[5] P. De Luca, R. Taddei, L. Varano, «Cyanidioschyzon merolae»: a new alga of thermal acidic environments, Webbia. 33 (1978) 37-44.

[6] R.W. Castenholz, T.R. McDermott, The Cyanidiales: ecology, biodiversity, and biogeography, in: Red Algae Genomic Age, Springer, 2010: pp. 357-371. 
[7] K.L. Van Alstyne, K.J. Anderson, D.H. van Hees, S. Gifford, Dopamine release by Ulvaria obscura (Chlorophyta): environmental triggers and impacts on photosynthesis, growth, and survival of the releaser, J. Phycol. 49 (2013) 719-727.

[8] J. Seckbach, Evolutionary pathways and enigmatic algae: Cyanidium caldarium (Rhodophyta) and related cells, Springer Science \& Business Media, 2012.

[9] S. Nagasaka, N.K. Nishizawa, T. Watanabe, S. Mori, E. Yoshimura, Evidence that electrondense bodies in Cyanidium caldarium have an iron-storage role, Biometals. 16 (2003) 465-470.

[10] P. Varshney, P. Mikulic, A. Vonshak, J. Beardall, P.P. Wangikar, Extremophilic micro-algae and their potential contribution in biotechnology, Bioresour. Technol. 184 (2015) 363-372.

[11] G. Barbier, C. Oesterhelt, M.D. Larson, R.G. Halgren, C. Wilkerson, R.M. Garavito, C. Benning, A.P.M. Weber, Comparative genomics of two closely related unicellular thermoacidophilic red algae, Galdieria sulphuraria and Cyanidioschyzon merolae, reveals the molecular basis of the metabolic flexibility of Galdieria sulphuraria and significant differences in carbo, Plant Physiol. 137 (2005) 460-474.

[12] C. Oesterhelt, W. Gross, Different Sugar Kinases Are Involved in the Sugar Sensing ofGaldieria sulphuraria, Plant Physiol. 128 (2002) 291-299.

[13] M.A. Greenquist, J.S. Drouillard, J.M. Sargeant, B.E. Depenbusch, X. Shi, K.F. Lechtenberg, T.G Nagaraja, Comparison of rectoanal mucosal swab cultures and fecal cultures for determining prevalence of Escherichia coli O157: H7 in feedlot cattle, Appl. Environ. Microbiol. 71 (2005) 6431-6433.

[14] W. Gross, I. Heilmann, D. Lenze, C. Schnarrenberger, Biogeography of the Cyanidiaceae (Rhodophyta) based on $18 \mathrm{~S}$ ribosomal RNA sequence data, Eur. J. Phycol. 36 (2001) 275-280.

[15] F.D. Ott, J. Seckbach, New classification for the genus Cyanidium Geitler 1933, in: Evol. Pathways Enigm. Algae Cyanidium Caldarium Relat. Cells, Springer, 1994: pp. 145-152.

[16] S. Cozzolino, P. Caputo, O. De Castro, A. Moretti, G. Pinto, Molecular variation in Galdieria sulphuraria (Galdieri) Merola and its bearing on taxonomy, Hydrobiologia. 433 (2000) 145-151.

[17] G. Pinto, P. Albertano, C. Ciniglia, S. Cozzolino, A. Pollio, H.S. Yoon, D. Bhattacharya, Comparative approaches to the taxonomy of the genus Galdieria merola (Cyanidiales, Rhodophyta), Cryptogamie-Algologie. 24 (2003) 13-32.

[18] A. Merola, R.C.P.D.R. Gambardella, A. Musacchio and R. Taddei. 1981, Revis. Cyanidium Caldarium. Three Species Acidophilic Algae. G. Bot. Ital. 115 (n.d.) 189195.

[19] M. Bimonte, A. De Lucia, A. Carola, A. Tito, S. Buono, A.L. Langellotti, Galdieria sulphuraria relieves oily and seborrheic skin by inhibiting the $5 \alpha$-Reductase expression in skin cells and reducing sebum production in vivo, Trichol. Cosmetol. Open J. 1 (2016) 11-18.

[20] U. SENTSOVA, On the diversity of acidothermophilic unicellular algae of the genus Galdieria (Rhodophyta, Cyanidiophyceae), Bot. Žurnal. 76 (1991) 69-78.

[21] H.M. Kim, C.H. Oh, H.-J. Bae, Comparison of red microalgae (Porphyridium cruentum) culture conditions for bioethanol production, Bioresour. Technol. $233 \quad$ (2017) 44-50. doi:https://doi.org/10.1016/j.biortech.2017.02.0 40.

[22] H.M. Kim, Y.G. Lee, D.H. Patel, K.H. Lee, D.S. Lee, H.-J. Bae, Characteristics of bifunctional acidic endoglucanase (Cel5B) from Gloeophyllum trabeum, J. Ind. Microbiol. Biotechnol. 39 (2012) 1081-1089.

[23] S.-H. Ho, S.-W. Huang, C.-Y. Chen, T. Hasunuma, A. Kondo, J.-S. Chang, Bioethanol production using carbohydrate-rich microalgae biomass as feedstock, Bioresour. Technol. 135 (2013) 191-198. doi:https://doi.org/10.1016/j.biortech.2012.10.0 15.

[24] S.-H. Ho, W.-M. Chen, J.-S. Chang, Scenedesmus obliquus CNW-N as a potential candidate for $\mathrm{CO} 2$ mitigation and biodiesel production, Bioresour. Technol. 101 (2010) 8725-8730.

[25] R.P. John, G.S. Anisha, K.M. Nampoothiri, A. Pandey, Micro and macroalgal biomass: a renewable source for bioethanol, Bioresour. Technol. 102 (2011) 186-193.

[26] G. Markou, I. Angelidaki, E. Nerantzis, D. Georgakakis, Bioethanol production by carbohydrate-enriched biomass of Arthrospira (Spirulina) platensis, Energies. 6 (2013) 39373950.

[27] A. Razaghi, A. Godhe, E. Albers, Effects of nitrogen on growth and carbohydrate formation in Porphyridium cruentum, Open Life Sci. 9 (2014) 156-162.

[28] K.H. Kim, I.S. Choi, H.M. Kim, S.G. Wi, H.-J. Bae, Bioethanol production from the nutrient stress-induced microalga Chlorella vulgaris by enzymatic hydrolysis and immobilized yeast fermentation, Bioresour. Technol. 153 (2014) 47-54.

[29] M. Martinez-Garcia, A. Kormpa, M.J.E.C. van der Maarel, The glycogen of Galdieria sulphuraria as alternative to starch for the production of slowly digestible and resistant glucose polymers, Carbohydr. Polym. 169 (2017) 75-82. doi:10.1016/j.carbpol.2017.04.004.

[30] R.A. Schmidt, M.G. Wiebe, N.T. Eriksen, Heterotrophic high cell-density fed-batch cultures of the phycocyanin-producing red alga Galdieria sulphuraria, Biotechnol. Bioeng. 90 (2005) 77-84. doi:10.1002/bit.20417.

[31] G. Graziani, S. Schiavo, M.A. Nicolai, S. Buono, V. Fogliano, G. Pinto, A. Pollio, Microalgae as human food: chemical and nutritional characteristics of the thermo-acidophilic microalga Galdieria sulphuraria., Food Funct. 4 (2013) 144-152. doi:10.1039/c2fo30198a. 
[32] J. Preiss, BACTERIAL GLYCOGEN SYNTHESIS AND ITS REGULATION, Annu. Rev. Microbiol. $38 \quad$ (1984) 419-458. doi:10.1146/annurev.mi.38.100184.002223.

[33] T. Sakurai, M. Aoki, X. Ju, T. Ueda, Y. Nakamura, S. Fujiwara, T. Umemura, M. Tsuzuki, A. Minoda, Profiling of lipid and glycogen accumulations under different growth conditions in the sulfothermophilic red alga Galdieria sulphuraria, Bioresour. Technol. 200 (2016) 861-866. doi:10.1016/j.biortech.2015.11.014.

[34] I. Maamoun, O. Eljamal, A.M.E. Khalil, Y. Sugihara, N. Matsunaga, Phosphate removal through nano-zero-valent iron permeable reactive barrier; column experiment and reactive solute transport modeling, Transp. Porous Media. 125 (2018) 395-412. doi:10.1007/s11242-0181124-0.

[35] R.W. Bailey, L.A. Staehelin, The chemical composition of isolated cell walls of Cyanidium caldarium, J. Gen. Microbiol. 54 (1968) 269-276. doi:10.1099/00221287-54-2-269.

[36] A. Minoda, H. Sawada, S. Suzuki, S. Miyashita, K. Inagaki, T. Yamamoto, M. Tsuzuki, Recovery of rare earth elements from the sulfothermophilic red alga Galdieria sulphuraria using aqueous acid, Appl. Microbiol. Biotechnol. 99 (2015) 15131519.

[37] X. Ju, K. Igarashi, S. Miyashita, H. Mitsuhashi, K. Inagaki, S. Fujii, H. Sawada, T. Kuwabara, A. Minoda, Effective and selective recovery of gold and palladium ions from metal wastewater using a sulfothermophilic red alga, Galdieria sulphuraria, Bioresour. Technol. 211 (2016) 759-764.

[38] E.-S. Salama, H.-S. Roh, S. Dev, M.A. Khan, R.A.I. Abou-Shanab, S.W. Chang, B.-H. Jeon, Algae as a green technology for heavy metals removal from various wastewater, World $\mathrm{J}$. Microbiol. Biotechnol. 35 (2019) 75.

[39] W.J. Oswald, C.G. Golueke, Biological transformation of solar energy, in: Adv. Appl. Microbiol., Elsevier, 1960: pp. 223-262.

[40] P. Young, M. Taylor, H.J. Fallowfield, Minireview: high rate algal ponds, flexible systems for sustainable wastewater treatment, World J. Microbiol. Biotechnol. 33 (2017) 117.

[41] N. Nirmalakhandan, T. Selvaratnam, S.M. Henkanatte-Gedera, D. Tchinda, I.S.A. Abeysiriwardana-Arachchige, H.M.K. DelankaPedige, S.P. Munasinghe-Arachchige, Y. Zhang, F.O. Holguin, P.J. Lammers, Algal wastewater treatment: Photoautotrophic vs. mixotrophic processes, Algal Res. 41 (2019) 101569. doi:https://doi.org/10.1016/j.algal.2019.101569.

[42] T. Selvaratnam, A.K. Pegallapati, H. Reddy, N. Kanapathipillai, N. Nirmalakhandan, S. Deng, P.J. Lammers, Algal biofuels from urban wastewaters: Maximizing biomass yield using nutrients recycled from hydrothermal processing of biomass, Bioresour. Technol. 182 (2015) 232238.

doi:https://doi.org/10.1016/j.biortech.2015.01.1 34.
[43] T. Selvaratnam, A.K. Pegallapati, F. Montelya, G. Rodriguez, N. Nirmalakhandan, W. Van Voorhies, P.J. Lammers, Evaluation of a thermotolerant acidophilic alga, Galdieria sulphuraria, for nutrient removal from urban wastewaters, Bioresour. Technol. 156 (2014) 395-399. doi:https://doi.org/10.1016/j.biortech.2014.01.0 75.

[44] S.M. Henkanatte-Gedera, T. Selvaratnam, M. Karbakhshravari, M. Myint, N. Nirmalakhandan, W. Van Voorhies, P.J. Lammers, Removal of dissolved organic carbon and nutrients from urban wastewaters by Galdieria sulphuraria: Laboratory to field scale demonstration, Algal Res. $24 \quad$ (2017) 450-456. doi:https://doi.org/10.1016/j.algal.2016.08.001.

[45] S.A. Ostroumov, T. V Shestakova, I. V Tropin, Biosorption of copper by biomass of extremophilic algae, Russ. J. Gen. Chem. 85 (2015) 2961-2964.

[46] O. Eljamal, K. Jinno, T. Hosokawa, Modeling of solute transport and biological sulfate reduction using low cost electron donor, Environ. Geol. 56 (2009) 1605-1613.

[47] O. Eljamal, J. Okawauchi, K. Hiramatsu, Removal of Phosphorus from Water Using Marble Dust as Sorbent Material, J. Environ. Prot. (Irvine,. Calif). $03 \quad$ (2012) 709-714. doi:10.4236/jep.2012.38084.

[48] O. Eljamal, K. Jinno, T. Hosokawa, Modeling of biologically mediated redox processes using sawdust as a matrix, Proc. Hydraul. Eng. 51 (2007) 19-24.

[49] O. Eljamal, A.M.E. Khalil, N. Matsunaga, Experimental and modeling column study of phosphorus removal by permeable reactive materials, Int. J. Environ. Agric. Res. 3 (2017) 62-70.

[50] O. Eljamal, I.P. Thompson, I. Maamoun, T. Shubair, K. Eljamal, K. Lueangwattanapong, Y. Sugihara, Investigating the design parameters for a permeable reactive barrier consisting of nanoscale zero-valent iron and bimetallic iron/copper for phosphate removal, J. Mol. Liq. 299 (2020) 112144.

[51] O. Falyouna, O. Eljamal, I. Maamoun, Removal of Cesium from Contaminated Waters by Employing Iron-Based Nanoparticles and Nanocomposites, Proceeding Int. Exch. Innov. Conf. Eng. Sci. 5 (2019) 26-27.

[52] R. Eljamal, O. Eljamal, I.P. Thompson, I. Maamoun, Upgrading of Aerobic Sequencing Batch Reactor System with Adding Nanoscale Zero Valent Iron for Wastewater Treatment, Proceeding Int. Exch. Innov. Conf. Eng. Sci. 5 (2019) 24-25.

[53] R. Eljamal, O. Eljamal, I. Maamoun, G. Yilmaz, Y. Sugihara, Enhancing the characteristics and reactivity of nZVI: Polymers effect and mechanisms, J. Mol. Liq. 315 (2020) 113714. doi:https://doi.org/10.1016/j.molliq.2020.11371 4.

[54] S. Alkhudhayri, O. Eljamal, I. Maamoun, R. Eljamal, Thermodynamic Effect on Boron Removal from Aqueous Solutions by $\mathrm{MgAl}$ 
Layered Double Hydrotalcite, Proceeding Int. Exch. Innov. Conf. Eng. Sci. 5.5 (2019) 19-21.

[55] O. Falyouna, O. Eljamal, I. Maamoun, A. Tahara, Y. Sugihara, Magnetic zeolite synthesis for efficient removal of cesium in a lab-scale continuous treatment system, J. Colloid Interface $\begin{array}{llll}\text { Sci. } & 571 & \text { (2020) }\end{array}$ doi:https://doi.org/10.1016/j.jcis.2020.03.028.

[56] R. Eljamal, I. Kahraman, O. Eljamal, I.P. Thompson, I. Maamoun, G. Yilmaz, Impact of nZVI on the formation of aerobic granules, bacterial growth and nutrient removal using aerobic sequencing batch reactor, Environ. Technol. Innov. $19 \quad$ (2020) 100911. doi:https://doi.org/10.1016/j.eti.2020.100911.

[57] I. Maamoun, O. Eljamal, R. Eljamal, O. Falyouna, Y. Sugihara, Promoting Aqueous and Transport Characteristics of Highly Reactive Nanoscale Zero Valent Iron via Different Layered Hydroxide Coatings, Appl. Surf. Sci. $506 \quad$ (2020) 145018 doi:https://doi.org/10.1016/j.apsusc.2019.14501 8.

[58] I. Maamoun, O. Eljamal, O. Falyouna, R. Eljamal, Y. Sugihara, Stimulating effect of magnesium hydroxide on aqueous characteristics of iron nanocomposites, Water Sci. Technol. (2020). doi:10.2166/wst.2020.027.

[59] I. Maamoun, O. Eljamal, T. Shubair, H. Noutsuka, B.B. Saha, N. Matsunaga, Integrating nano-scale zero valent iron (nZVI) in phosphorus removal from aqueous solution through porous media: packed-column experiment, Proc. Int. Exch. Innov. Conf. Eng. Sci. 3 (2017) 25-30.

[60] I. Maamoun, O. Eljamal, N. Matsunaga, Enhancement of Nanoscale Zero-Valent Iron Stability in Aqueous Solution Via Metal Hydroxide Coating, (2018).

[61] I. Maamoun, O. Eljamal, O. Falyouna, R. Eljamal, Y. Sugihara, Multi-objective optimization of permeable reactive barrier design for $\mathrm{Cr}$ (VI) removal from groundwater, Ecotoxicol. Environ. Saf. 200 (2020) 110773.

[62] I. Maamoun, O. Eljamal, I. Thompson, R. Eljamal, O. Falyouna, Y. Sugihara, Effect of Nano Zero Valent Iron Delivery Method into Porous Media on Phosphorus Removal from Groundwater, Proc. Int. Exch. Innov. Conf. Eng. Sci. 5 (2019) 9-11.

[63] S. Takami, O. Eljamal, A.M.E. Khalil, R. Eljamal, N. Matsunaga, Development of continuous system based on nanoscale zero valent iron particles for phosphorus removal, J. Japan Soc. Civ. Eng. 7 (2019) 30-42. doi:10.2208/journalofjsce.7.1_30.

[64] O. Eljamal, J. Okawauchi, K. Hiramatsu, Product rich in phosphorus produced from phosphoruscontaminated water, in: Adv. Mater. Res., Trans Tech Publ, 2014: pp. 261-265.

[65] O. Eljamal, K. Jinno, T. Hosokawa, Modeling of solute transport with bioremediation processes using sawdust as a matrix, Water. Air. Soil Pollut. 195 (2008) 115-127.

[66] O. Eljamal, K. Sasaki, T. Hirajima, Sorption Kinetic of Arsenate as Water Contaminant on
Zero Valent Iron, J. Water Resour. Prot. 05 (2013) 563-567. doi:10.4236/jwarp.2013.56057.

[67] A.M.E. Khalil, O. Eljamal, B.B. Saha, N. Matsunaga, Performance of nanoscale zerovalent iron in nitrate reduction from water using a laboratory-scale continuous-flow system, Chemosphere. $197 \quad$ (2018) 502-512. doi:https://doi.org/10.1016/j.chemosphere.2018. 01.084 . 